\begin{tabular}{|l|l|l||}
\hline \multicolumn{2}{|c|}{ PublisherInfo } \\
\hline \hline PublisherName & $:$ & BioMed Central \\
\hline \hline PublisherLocation & $:$ & London \\
\hline \hline PublisherImprintName & $:$ & BioMed Central \\
\hline \hline
\end{tabular}

\title{
A lot of bloody genes
}

\begin{tabular}{|l|l|l||}
\hline \multicolumn{2}{|c|}{ ArticleInfo } \\
\hline \hline ArticleID & $:$ & 3695 \\
\hline \hline ArticleDOI & $:$ & $10.1186 /$ gb-spotlight-20000607-01 \\
\hline \hline ArticleCitationID & $:$ & spotlight-20000607-01 \\
\hline \hline ArticleSequenceNumber & $:$ & 132 \\
\hline \hline ArticleCategory & $:$ & Research news \\
\hline \hline ArticleFirstPage & $:$ & 1 \\
\hline \hline ArticleLastPage & $:$ & 2 \\
\hline \hline & & RegistrationDate : 2000-06-07 \\
ArticleHistory & $:$ & OnlineDate $\quad$ 2000-06-07 \\
\hline \hline ArticleCopyright & $:$ & BioMed Central Ltd2000 \\
\hline \hline ArticleGrants & $:$ & \\
\hline \hline ArticleContext & $:$ & 130591111 \\
\hline \hline
\end{tabular}




\section{William Wells}

Email: wells@biotext.com

In the 2 June Science, Phillips et al. announce the creation of the Stem Cell Database (SCDb), an annotated collection of genes expressed in hematopoietic stem cells (Science 2000, 288:1635-1640). Most of the data are based on the sequencing of 5735 clones from a subtracted stem cell library, representing at least half of the library's complexity. The $\mathrm{SCDb}$ reveals clues to stem cell biology, such as the coincidence of semaphorins and their ligands, suggesting that these molecules are important for stem cell adhesion and homing. But, perhaps most importantly, the list of genes will serve as the basis for stem cell microarrays that can be used to analyze changes in regulatory networks as stem cells renew and differentiate.

\section{References}

1. Science Magazine, [http://www.sciencemag.org/]

2. Princeton stem cell database, [http://stemcell.princeton.edu/] 